\title{
SALES BUDGET ANALYSIS IN REVIEW OF SOME FORECASTING METHODS IN EFFORTS TO INCREASE INCOME AT PT. NM MANADO
}

\author{
Denny I.Y Rompas \\ Department Of Accounting, Polytechnic of Manado Country \\ DOI: 10.31364/SCIRJ/v9.i04.2021.P0421852 \\ http://dx.doi.org/10.31364/SCIRJ/v9.i04.2021.P0421852
}

\begin{abstract}
The purpose of this research is to determine the sales budget which is reviewed by the forecasting method, namely using the Semi Average Trend, Moment Trend and Least Square Trend in an effort to increase the profit of PT. NM Manado, and want to know which forecasting method is more profitable. The research method used in this research is comparative quantitative. Quantitative comparative, namely the preparation of a sales budget that is reviewed in various forecasting methods to increase profits, as well as to find out which forecasting method is more suitable for use in the preparation of a sales budget at PT. NM Manado. Techniques for obtaining data about the object to be studied include: interviews, documentation and observation. The results showed that the sales budget using the least squares method was more profitable than the other two forecasting methods.
\end{abstract}

Keywords: Semi Average Trend, Moment Trend, Least Square

\section{INTRODUCTION}

The development of globalization in the business world is becoming increasingly rapid due to the presence of increasingly sophisticated technology that supports economic growth. This can be seen from the fierce and creative business competition, making business people always try to maintain their business in achieving an expected goal. The goal of the company is to get the maximum profit or profit, in order to finance the company's life and to make the company more developed and advanced. Therefore, in order for company activities to be more effective and efficient, a budget is needed.

According to Mulyadi (2015) Budget is a work plan that is expressed quantitatively as measured in standard monetary units and other units of measure covering a period of one year. With a budget, management directs the company's conditions. Without a budget, in the short term the company will run without direction, at the expense of uncontrolled resources.

Uncontrolled resources are of course detrimental to the company. Therefore, the sales budget has a strategic role in supporting the company to achieve its goals, namely profit. Therefore, companies need to make predictions of what will happen in the future. According to Jay Heizer and Barry Render (2011) forecasting is the art and science of predicting future events by involving taking historical data and projecting it into the future with a systematic approach model.

Based on sales budget data and its realization. PT. NM Manado, in 2016 the sales budget was IDR $53,970,800,620.00$, then the realization at the end of 2016 was IDR 54,220,990,452.00. This means that the sales budget reached the target, even more than what was budgeted. Here in 2017 the sales budget is IDR 54,273,121,421.00, and the realization is IDR 52,602,323,473.00, so the difference is less / not achieved IDR 1,670,797,948.00. In 2018 the company made a sales budget of IDR 55,803,774,022.00, and realized budget of IDR 55,984,700,320.00. In 2019 the sales budget that the company re-created was Rp. 55,972,003,454.00, and the realization was Rp. 54,790,820,000.00. The difference between less / not achieved by the company is IDR 1,181,183,454.00. Based on the background above, the problem formulations in this research are:

1. How to prepare a sales budget in terms of various forecasting methods, namely the Semi Average Trend, Moment Trend and Least Square Trend in an effort to increase profits at PT. NM Manado? 
2. Which method of forecasting is more profitable, if used in the sales budget preparation process at PT. NM Manado?

\section{RESEARCH METHODS}

The research method used in this research is comparative quantitative. Quantitative comparative, namely the preparation of a sales budget that is reviewed in various forecasting methods in order to increase profits, as well as to find out which forecasting method is more appropriate, to be used in the preparation of a sales budget at PT.NM Manado. Data collection techniques were obtained, namely: 1) Primary data. Primary data is data obtained directly from related parties, and data obtained without going through the processing process. Researchers obtained primary data through interviews conducted with employees of PT.NM Manado, especially in the Sales \& Marketing section. 2). Secondary Data, Secondary data is data that has been processed. In this study, the source of research data was the sales data of PT.NM Manado in the period 2016 to 2019. Techniques for obtaining data about the object to be studied, including: interviews, documentation and observation.

\section{DISCUSSION}

PT. NM Manado prepares an annual sales budget. The data contained in PT. NM Manado is the budget and realization data obtained by the company for the last four years. The following is budget data and sales realization at PT. NM Manado in 2016 to 2019 can be seen in table 3.1 below:

Table 3.1 Budget and Realization of Sales 2016-2019 (IDR)

\begin{tabular}{|c|c|c|c|}
\hline \multirow{2}{*}{ Year } & Sales Budget & Realization & Difference \\
\hline 2016 & $53,970,800,620.00$ & $54,220,990,452.00$ & $250,189,832.00$ \\
\hline 2017 & $54,273,121,421.00$ & $52,602,323,473.00$ & $-1,670,797,948.00$ \\
\hline 2018 & $55,803,774,022.00$ & $55,984,700,320.00$ & $180,926,298.00$ \\
\hline 2019 & $55,972,003,454.00$ & $54,790,820,000.00$ & $-1,181,183,454.00$ \\
\hline
\end{tabular}

Source: Processed Data, 2021

Based on table 3.1 above that the budget and sales realization at PT. NM Manado experienced a difference. The sales realization in 2017 and 2019 experienced a quite high difference from the budget made, in contrast to 2016 and 2018 the realization of the budget was achieved.

\section{Preparation of Sales Budget Forecast Using the Semi Average Trend Method, Trend Moment and Least Squares}

Trend.

a. Semi Average Method

Table 3.2 Calculation of Sales Forecast Trend

Trend Method, Semi Average 2016 - 2019 (IDR)

\begin{tabular}{|c|c|c|c|c|c|}
\hline Year & \multirow{2}{*}{ Sales $(\boldsymbol{Y})$} & $\mathbf{X}$ & Semi Total & Semi Average \\
\hline \multirow{2}{*}{2016} & & $54,220,990,452.00$ & -2 & & \\
\cline { 4 - 6 } & \multirow{3}{*}{1} & & & $106,823,313,925.00$ & $53,411,656,962.50$ \\
\cline { 3 - 6 } & & & & & \\
\hline
\end{tabular}


ISSN 2201-2796

\begin{tabular}{|c|c|c|c|c|c|}
\hline \multirow[t]{2}{*}{2018} & \multirow{3}{*}{2} & $55,984,700,320.00$ & 1 & & \\
\hline & & & & $110,775,520,320.00$ & $55,387,760,160.00$ \\
\hline 2019 & & $54,790,820,000.00$ & 2 & & \\
\hline 2020 & & $?$ & 3 & & \\
\hline
\end{tabular}

Source: Processed Data, 2021

$$
\begin{aligned}
& \mathrm{a}=\text { Group average } 1 \\
& \mathrm{~b}=\frac{\mathrm{X} 2-\mathrm{X} 1}{\mathrm{n}}
\end{aligned}
$$

Intermediate value:

$\underline{\text { IDR } 106,823,313,925.00}=$ IDR 53,411,656,962.50 2

$\mathrm{b}=\underline{\mathrm{IDR} .55,387,760,160.00-\mathrm{IDR} .53,411,656,962.50}=\mathrm{IDR} .988,051,598.75$ 2

With the Trend line equation:

$\mathrm{Y}=\mathrm{a}+\mathrm{bX} \quad \mathrm{Y}=$ IDR 53,411,656,962.50+ IDR. 988,051,598.75X 
Table 3.3 Trend Value Calculation Semi Trend method average

2016 - 2024 (IDR)

\begin{tabular}{|c|c|}
\hline Year & $\mathbf{Y}=\mathbf{a}+\mathbf{b X}$ \\
\hline 2016 & $53,411,656,962.50+988,051,598.75(-2)=51,435,553,765.00$ \\
\hline 2017 & $53,411,656,962.50+988,051,598.75(-1)=52,423,605,364.00$ \\
\hline 2018 & $53,411,656,962.50+988,051,598.75(1)=54,399,708,561.00$ \\
\hline 2019 & $53,411,656,962.50+988,051,598.75(2)=55,387,760,160.00$ \\
\hline 2020 & $53,411,656,962.50+988,051,598.75(3)=56,375,811,759.00$ \\
\hline 2022 & $53,411,656,962.50+988,051,598.75(4)=57,363,863,358.00$ \\
\hline 2023 & $53,411,656,962.50+988,051,598.75(5)=58,351,914,956.00$ \\
\hline & $53,411,656,962.50+988,051,598.75(6)=59,339,96,555.00$ \\
\hline
\end{tabular}

Source: Processed Data, 2021

Based on the results of calculations using the semi-average trend method, it is known that the total sales forecast from the previous years to the following years is 988,051,599.00. The semi-average method is rarely used by most companies because of its simple use of variables, so that it can make several factors not considered in the calculation process, one of which is external factors that cannot be controlled by the company.

\section{b. Metode Trend Moment} below:

Total sales generated by PT. NM Manado is done using the Trend Moment Method, which can be seen in Table 3.4

\section{Table 3.4 Calculation of Sales Forecast Trend Trend Moment Method 2016 - 2019 (IDR)}

\begin{tabular}{|c|c|c|c|c|c|}
\hline Number & Year & Sales $(\boldsymbol{Y})$ & $\mathbf{X}$ & $\mathbf{X}^{\mathbf{2}}$ \\
\hline 1 & 2016 & $54,220,990,452.00$ & 0 & 0 \\
\hline 2 & 2017 & $52,602,323,473.00$ & 1 & $52,602,323,473.00$ \\
\hline 3 & 2018 & $55,984,700,320.00$ & 2 & $111,969,400,640.00$ & 4 \\
\hline 4 & 2019 & $54,790,820,000.00$ & 3 & $164,372,460,000.00$ & 9 \\
\hline & \multirow{2}{*}{$\Sigma$} & $217,598,834,245.00$ & 6 & $328,944,184,113.00$ & 14 \\
\cline { 3 - 6 } & & $\Sigma \mathrm{Y}$ & $\Sigma \mathrm{X}$ & $\Sigma \mathrm{XY}$ & $\Sigma \mathrm{X}^{2}$ \\
\hline
\end{tabular}

Source: Processed Data, 2021

From the results of the summation data table above, it is then applied to the formula as follows: 


$$
Y=a+b X
$$

(i) $\Sigma \mathrm{Y}=\mathrm{a} . \mathrm{n}+\mathrm{b} \Sigma \mathrm{x}$

Elimination calculation: :

(ii) $\Sigma X Y=a \Sigma x+b \Sigma x^{2}$

(i) IDR $217,598,834,245.00=4 a+6 b \ldots \ldots \ldots \times 3$

(ii) IDR $\underline{328,944,184,113.00=6 a+14 b \ldots \ldots \ldots . . \times 2}$ -

IDR $652,796,502,735.00=12 \mathrm{a}+18 \mathrm{~b}$

IDR $\underline{657,888,368,226.00=12 a+24 b-}$

IDR $(-5,091,865,491.00)=-6 b$

$\mathrm{b}=\operatorname{IDR} \underline{(-5,091,865,491.00}$

$\mathrm{b}=$ IDR $848,644,248.50$

To find the value of $a$, the value of $b$ is substituted for equation (i)

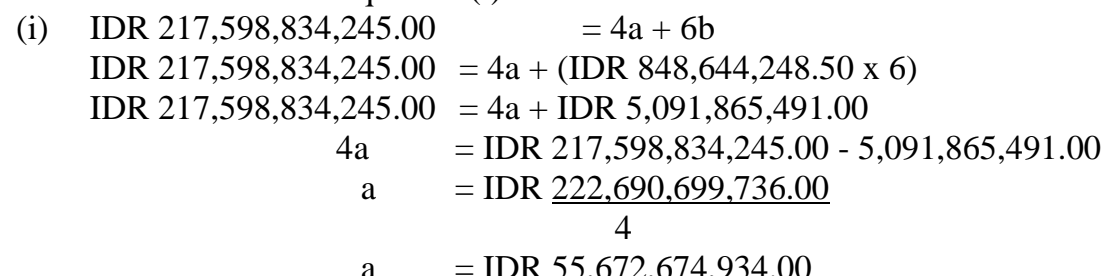

After the $\mathrm{a}$ and $\mathrm{b}$ values are known, the results are substituted into the trend equation $\mathrm{Y}=\mathrm{a}+\mathrm{bX}$, so that the trend equation becomes:

$$
\mathrm{Y}=55,672,674,934.00+848,644,248.50 \mathrm{X}
$$

The following table for calculating the sales forecast for 2016 to 2024 can be seen in table 3.5 below:

Table 3.5 Calculation of Sales Forecast, Trend Moment Method $2016-2024$ (IDR)

\begin{tabular}{|c|c|}
\hline Year & $\mathbf{Y}=\mathbf{a}+\mathbf{b X}$ \\
\hline 2016 & $\mathrm{Y}=55,672,674,934.00+848,644,248.50(0) \quad=55,672,674,934.00$ \\
\hline 2017 & $Y=55,672,674,934.00+848,644,248.50(1) \quad=56,521,319,182.50$ \\
\hline 2018 & $Y=55,672,674,934.00+848,644,248.50(2) \quad=57,369,963,431.00$ \\
\hline 2019 & $Y=55,672,674,934.00+848,644,248.50(3) \quad=58,218,607,679.50$ \\
\hline 2020 & $Y=55,672,674,934.00+848,644,248.50(4) \quad=59,067,251,928.00$ \\
\hline 2021 & $Y=55,672,674,934.00+848,644,248.50(5) \quad=59,915,896,176.50$ \\
\hline 2022 & $Y=55,672,674,934.00+848,644,248.50(6) \quad=60,764,540,425.00$ \\
\hline 2023 & $Y=55,672,674,934.00+848,644,248.50(7) \quad=61,613,184,673.50$ \\
\hline 2024 & $Y=55,672,674,934.00+848,644,248.50(8) \quad=62,461,828,922.00$ \\
\hline
\end{tabular}

Source: Processed Data, 2021

Based on calculations using the Moment forecasting method, it can be seen that the increase in total sales each year PT. NM Manado, amounting to IDR 848,644,249.00. By using this method, the target to be achieved by the company for 
the following years will continue to increase, therefore it requires more enthusiasm, optimism and performance for the company to achieve the desired target in increasing profits.

\section{c. Metode Trend Kuadrat Terkecil (Least Square)}

In this method, fewer and simpler variables are used, so the calculation is the easiest among other methods. The following is historical data about the total sales generated by PT. NM Manado is done using the Least Square Trend Method, it will look like in table 3.6 below:

Table 3.6 Sales Calculation for Least Square Method 2016 - 2019 (IDR)

\begin{tabular}{|c|c|c|c|c|c|}
\hline Number & Year (n) & Sales (Y) & $\mathrm{X}$ & $\mathrm{X} 2$ & $\mathrm{XY}$ \\
\hline 1 & 2016 & \multirow{4}{*}{$\begin{array}{l}54,220,990,452.00 \\
52,602,323,473.00 \\
55,984,700,320.00 \\
54,790,820,000.00\end{array}$} & -2 & 4 & $-108,441,980,904.00$ \\
\hline 2 & 2017 & & -1 & 1 & $-52,602,323,473.00$ \\
\hline 3 & 2018 & & 1 & 1 & $55,984,700,320.00$ \\
\hline 4 & 2019 & & 2 & 4 & $109,581,640,000.00$ \\
\hline & & $217,598,834,245.00$ & - & 10 & $4,522,035,943.00$ \\
\hline
\end{tabular}

Source: Processed Data, 2021

With the Trend equation: $Y=a+b X$

Where is the formula

$$
\begin{aligned}
& \text { (i) } a=\frac{\Sigma \gamma}{\mathrm{n}} \\
& \text { (ii) } b=\frac{\Sigma \mathrm{x} \gamma}{\Sigma \mathrm{x}^{2}}
\end{aligned}
$$

So that the calculation is as follows:

(i) $\quad a=\frac{\Sigma \gamma}{\mathrm{n}}=\underline{217,598,834,245.00}=54,399,708,561.25$

(ii) $\mathrm{b}=\frac{\Sigma \mathrm{x} \gamma}{\Sigma \mathrm{x}^{2}}=\underline{-323,852,318,622.00}=452,203,594.30$

After the $a$ and $b$ values are known, they are substituted into the trend equation:

Formula $: \mathrm{Y}=\mathrm{a}+\mathrm{bX}$ : So that the equation becomes :

$\mathrm{Y}=54,399,708,561.25+452,203,594.30 \mathrm{X}$

Table 3.7 Calculation of Sales Forecast Least Square Trend Method 2016 - 2024 (IDR)

\begin{tabular}{|c|c|}
\hline Year & $\mathbf{Y = a + b X}$ \\
\hline 2016 & $54,399,708,561.25+452,203,594.30(-2)=53,495,301,373.00$ \\
\hline 2017 & $54,399,708,562.25+452,203,595.30(-1)=53,947,504,967.00$ \\
\hline
\end{tabular}




\begin{tabular}{|c|c|}
\hline 2018 & $54,399,708,563.25+452,203,595.30(1)=54,851,912,156.00$ \\
\hline 2019 & $54,399,708,564.25+452,203,595.30(2)=55,304,115,750.00$ \\
\hline 2020 & $54,399,708,565.25+452,203,595.30(3)=55,756,319,344.00$ \\
\hline 2021 & $54,399,708,566.25+452,203,595.30(4)=56,208,522,938.00$ \\
\hline 2022 & $54,399,708,567.25+452,203,595.30(5)=56,660,726,533.00$ \\
\hline 2023 & $54,399,708,568.25+452,203,595.30(6)=57,112,930,127.00$ \\
\hline 2024 & \\
\hline
\end{tabular}

Source: Processed Data, 2021

Based on the results of calculations using the least squares trend method, it is known that the total sales of PT. NM Manado, for the following years as much as IDR 452,203,594.00. The least squares method is often used by many companies in preparing sales budget forecasts because of its more practical and simpler use. From the results of calculations using this method, the total sales forecast for the following years is closer to realization. So that it can be an alternative choice for the company, because in estimating sales results using this method. The forecast results obtained are the lowest compared to the other two methods.

\section{Forecasting Error Standards}

NThe smallest standard value of Forecasting Error will show that the forecast is close to conformity. To determine which method is most suitable in selecting forecasts, companies can compare the results of the forecast by using the Semi Average trend method, the Moment trend method, and the Least Squares trend method or using other methods. However, in preparing the sales forecast this time the author uses the Semi Average trend method, the Moment trend method, and the Least Square trend method in calculating sales forecasts, so that companies can compare and choose which method is most suitable to be applied in preparing sales budgets to increase sales. corporate profits. Below is table 3.8, namely the comparison of sales realization, sales forecasts based on the calculation results with the forecasting method that has been made.

Table 3.8 Comparison Using Sales Forecasting Methods

The Method of Average Spring Trend, Trend Moment and Least Squares Trend 2016 - 2019 (IDR)

\begin{tabular}{|c|c|c|c|c|}
\hline \multirow{2}{*}{ Year } & Budget Realization & \multicolumn{3}{|c|}{ Sales Budget Forecast } \\
\cline { 2 - 5 } & & Semi Average & Moment & Least Square \\
\hline 2016 & $54,220,990,452.00$ & $51,435,553,765.00$ & $55,672,674,934.00$ & $53,495,301,373.00$ \\
\hline 2017 & $52,602,323,473.00$ & $52,423,605,364.00$ & $56,521,319,182.50$ & $53,947,504,967.00$ \\
\hline 2018 & $55,984,700,320.00$ & $54,399,708,561.00$ & $57,369,963,431.00$ & $54,851,912,156.00$ \\
\hline 2019 & $54,790,820,000.00$ & $55,387,760,160.00$ & $58,218,607,679.50$ & $55,304,115,750.00$ \\
\hline 2020 & - & $56,375,811,759.00$ & $59,067,251,928.00$ & $55,756,319,344.00$ \\
\hline 2021 & - & $57,363,863,358.00$ & $59,915,896,176.50$ & $56,208,522,938.00$ \\
\hline 2022 & - & $58,351,914,956.00$ & $60,764,540,425.00$ & $56,660,726,533.00$ \\
\hline 2023 & - & $59,339,966,555.00$ & $61,613,184,673.50$ & $57,112,930,127.00$ \\
\hline 2024 & - & $60,328,018,154.00$ & $62,461,828,922.00$ & $57,565,133,721.00$ \\
\hline
\end{tabular}

Source: Processed Data, 2021

www.scirj.org

(C) 2021, Scientific Research Journal

http://dx.doi.org/10.31364/SCIRJ/v9.i04.2021.P0421852

This publication is licensed under Creative Commons Attribution CC BY. 
The smallest standard error of forecasting will show that the forecast is compiled close to the realization that occurs in the company. Below is the calculation of the standard error for forecasting sales at PT. NM Manado which is reviewed according to the following prediction methods:

a. Calculation of Standard Error Forecasting Semi-Average Method

\section{Table 3.9 Standard Calculation of Forecast Error \\ Semi Average Method \\ $2016-2019$ (IDR)}

\begin{tabular}{|c|c|c|c|c|}
\hline Year & $\begin{array}{c}\text { Realization of Sales } \\
(\mathbf{X})\end{array}$ & $\begin{array}{c}\text { Sales Forecast } \\
(\mathbf{Y})\end{array}$ & $(\mathbf{X}-\mathbf{Y})$ & $\left(^{\mathbf{X}-\mathbf{Y})^{2}}\right.$ \\
\hline 2016 & $54,220,990,452.00$ & $51,435,553,765.00$ & $2,785,436,687.00$ & $7,758,657,537,285,540,000.00$ \\
\hline 2017 & $52,602,323,473.00$ & $52,423,605,364.00$ & $178,718,109.00$ & $31,940,162,484,535,900.00$ \\
\hline 2018 & $55,984,700,320.00$ & $54,399,708,561.00$ & $1,584,991,759.00$ & $2,512,198,876,097,910,000.00$ \\
\hline 2019 & $54,790,820,000.00$ & $55,387,760,160.00$ & $(596,940,160.00)$ & $356,337,554,620,826,000.00$ \\
\hline \multicolumn{3}{|r|}{ Amount } & $10,659,134,130,488,800,000.00$ \\
\hline
\end{tabular}

Source: Processed Data, 2021

$$
\begin{aligned}
\text { SKP } & \left.=\sqrt{\left\{(X-Y)^{2}\right.}: n\right\} \\
& =\frac{\sqrt{10,659,134,130,488,800,000.00}}{4} \\
& =\sqrt{2,664,783,532,622,200,000.00} \\
& =\text { IDR } 1,632,416,470.34
\end{aligned}
$$

b. Calculation of Moment Method Error Forecasting Standard

Table 3.10 Calculation of Standard Error Forecasting Trend Moment Method 2016 - 2019 (IDR)

\begin{tabular}{|c|c|c|c|c|}
\hline Year & $\begin{array}{c}\text { Realization of Sales } \\
(\mathbf{X})\end{array}$ & $\begin{array}{c}\text { Sales Forecast } \\
(\mathbf{Y})\end{array}$ & $(\mathbf{X}-\mathbf{Y})$ & $(\mathbf{X}-\mathbf{Y})^{2}$ \\
\hline 2016 & $54,220,990,452.00$ & $55,672,674,934.00$ & $(1,451,684,482.00)$ & $2,107,387,835,279,610,000.00$ \\
\hline 2017 & $52,602,323,473.00$ & $56,521,319,182.50$ & $(3,918,995,709.50)$ & $15,358,527,371,079,400,000.00$ \\
\hline 2018 & $55,984,700,320.00$ & $57,369,963,431.00$ & $(1,385,263,111.00)$ & $1,918,953,886,697,400,000.00$ \\
\hline 2019 & $54,790,820,000.00$ & $58,218,607,679.50$ & $(3,427,787,679.50)$ & $11,749,728,375,732,000,000.00$ \\
\hline \multicolumn{3}{|c|}{ Amount } & $31,134,597,468,788,400,000.00$ \\
\hline
\end{tabular}

Source: Processed Data, 2021

$$
\begin{aligned}
\text { SKP } & \left.=\sqrt{\left\{(X-Y)^{2}\right.}: n\right\} \\
& =\frac{\sqrt{31,134,597,468,788,400,000.00}}{4} \\
& =\sqrt{7,783,649,367,197,100,000.00} \\
& =2,789,919,240.26
\end{aligned}
$$


c. Calculation of Standard Error Forecasting (SEF) Least Square Trend Method

Table 3.11 Calculation of Forecasting Error Standards (SKP)

Least Square Trend Method

2016 - 2019 (IDR)

\begin{tabular}{|c|l|l|c|c|}
\hline Year & $\begin{array}{c}\text { Realization of Sales } \\
(\mathbf{X})\end{array}$ & $\begin{array}{c}\text { Sales Forecast } \\
(\mathrm{Y})\end{array}$ & $\mathbf{( X - Y )}$ & $\mathbf{( X )}^{\mathbf{X}-\mathbf{Y})^{2}}$ \\
\hline 2016 & $54,220,990,452.00$ & $53,495,301,373.00$ & $725,689,079.00$ & $526,624,639,379,868,000.00$ \\
\hline 2017 & $52,602,323,473.00$ & $53,947,504,967.00$ & $(1,345,181,494.00)$ & $1,809,513,251,800,070,000.00$ \\
\hline 2018 & $55,984,700,320.00$ & $54,851,912,156.00$ & $1,132,788,164.00$ & $1,283,209,024,498,490,000.00$ \\
\hline 2019 & $54,790,820,000.00$ & $55,304,115,750.00$ & $(513,295,750.00)$ & $263,472,526,968,062,000.00$ \\
\hline \multicolumn{3}{|c|}{ Amount } & $3,882,819,442,646,490,000.00$ \\
\hline
\end{tabular}

Source: Processed Data, 2021

$$
\begin{aligned}
\mathrm{SEF} & \left.=\sqrt{\left\{(X-Y)^{2}\right.}: n\right\} \\
& =\frac{\sqrt{3,882,819,442,646,490,000.00}}{4} \\
& =\sqrt{970,704,860,661,623,000.00} \\
& =985,243,553.98
\end{aligned}
$$

Dari From the calculation of the Forecasting Error Standards above, the comparison can be seen in table 4:12 below:

Table 3.12 Comparison of Forecasting Error Standards

The Method of Average Spring Trend, Trend Moment and Least Squares Trend

\begin{tabular}{|c|c|c|}
\hline Number & Method & \multicolumn{2}{|c|}{ Forecasting Error Standards } \\
\hline 1 & Semi Average & IDR. $1,632,416,470.34 .00$ \\
\hline 2 & Moment & IDR. $2,789,919,240.00$ \\
\hline 3 & Least Square & IDR. $985,243,554.00$ \\
\hline
\end{tabular}

Sumber : Data primer yang diolah, 2021

Based on the comparison of the data, it can be seen the comparison of the standard error of forecasting on the trend methods used. It can be seen that the least squares method has smaller results than the other methods.

\section{CONCLUSION}

Based on the analysis of the sales budget data of PT. NM Manado for the period 2016 to 2019 in terms of various forecasting methods, namely as follows:

1. PT. NM Manado has used the calculation method (application) set by the company to estimate sales for the following year. Therefore, the sales data for 2016 to 2019 have varied results. It is known that in 2016 and 2018 sales reached the target, while in 2017 and 2019 sales did not reach the target.

2. From the results of the above discussion, the researcher uses the comparative quantitative method, so it can be concluded that the comparison of the sales budget calculation uses the forecasting method in terms of the Semi Average Trend, Moment Trend and Least Square Trend. Produces variable trend values and variable calculations, there are practical and simple variables, some are complicated. So that it can be seen the strengths and weaknesses of 
each trend method that is suitable for use. The forecasting method, namely the Least Square, is more profitable than the other two forecasting methods.

Based on some of the conclusions that the researchers have summarized above, the authors recommend several things, namely as follows:

1. In preparing a sales budget, the manager should be able to include several marketing or related employees in setting or approving sales targets, so that related employees can be more motivated and established communication, cooperation and even more responsibility in achieving budgeted sales targets together.

2. From the results of the discussion to determine the sales budget forecast, the company should use the forecasting method, namely the Least Square compared to the other two forecasting methods.

3. Based on the calculation of the Standard Error Forecasting, it shows that the forecasting method is close to conformity, where the smallest level of the sales trend is the Least Square Trend Method. In addition, the Trend Moment method produces the highest sales trend level. Therefore, when viewed from these various forecasting methods, according to the researcher, the company can consider it to be applied in preparing a sales budget in order to increase company profits.

\section{REFERENCES}

Dharmanegara, Ida Bagus Agrung. 2010. Corporate Budgeting-First Edition. Yogyakarta; Graha science. Didit Herlianto, 2015. Financial Budget - First Edition. Yogyakarta: Gosyen Publishing

Dini Meiliani. 2016. Sales Budget Analysis At CV. Joint ventures. http://repository.umpalembang.ac.id/id/eprint/1323/1/SKRIPSI1123-1711284853. (accessed August 2016)

E, Ulfi. 2016. Definition of Budget. http://eprints.polsri.ac.id/3341/3/BAB\%20II. (accessed 2016)

Fajri.2010. Budget Characteristics. http://eprints.polsri.ac.id/2548/3/BAB\%20II.pdf. (Accessed 2015)

Haruman, Tendi \& Sri, Rahayu. 2007. Preparation of Company Budget. Second Edition. Yogyakarta: Graha science.

Husnayetti, 2012. Company Budget - First Edition. Tanggerang: Jelajah Nusa

Kho, Budhi. 2011. Definition of Forecasting and Forecasting Steps. https://ilmumana Manajemenindustri.com/pengentukperamalan-forecasting/. (accessed 14 May 2018)

Mulyadi. 2015. Cost Accounting, 5th Edition. Yogyakarta: YKPN College of Management.

Nabilah \& Harry Roestiono. 2015. Sales Budget Analysis in Increasing Company Profits. Https://www.researchgate.net/publication/329088266 Analysis Of Sales Budget In Increasing Company Profit. (accessed November 2018) 